\title{
Botany
}

\section{Contrasting root overwintering strategies of perennial wetland monocots}

\begin{tabular}{|c|c|}
\hline Journal: & Botany \\
\hline Manuscript ID & cjb-2018-0065.R1 \\
\hline Manuscript Type: & Article \\
\hline Date Submitted by the Author: & 13-Jun-2018 \\
\hline Complete List of Authors: & $\begin{array}{l}\text { Nieman, Tim; University of Amsterdam, Institute for Biodiversity and } \\
\text { Ecosystem dynamics- Physical Geography } \\
\text { Hoogzaad, Yvonne; University of Amsterdam, Institute for Biodiversity and } \\
\text { Ecosystem dynamics- Physical Geography } \\
\text { Marcotte, Susara; Laurentian University Department of Biology } \\
\text { Ryser, Peter; Laurentian University, Biology }\end{array}$ \\
\hline Keyword: & phenology, root turnover, root mortality, seasonal climate, wetland \\
\hline $\begin{array}{r}\text { Is the invited manuscript for } \\
\text { consideration in a Special } \\
\text { Issue? : }\end{array}$ & Not applicable (regular submission) \\
\hline
\end{tabular}




\section{Contrasting root overwintering strategies of perennial wetland monocots}

3 Tim Nieman

4 University of Amsterdam

5 Institute for Biodiversity and Ecosystem dynamics- Physical Geography

61018 WV Amsterdam

7 tim-nieman@outlook.com

8

9 Yvonne Hoogzaad

10 University of Amsterdam

11 Institute for Biodiversity and Ecosystem dynamics- Physical Geography

121018 WV Amsterdam

13 yvonne_hoogzaad@hotmail.com

14

15 Susara JE Marcotte,

16 Laurentian University, Department of Biology

17935 Ramsey Lake Road, Sudbury, Ontario, Canada P3E 2C6

18 elizemarcotte@gmail.com

19

20 Peter Ryser (Corresponding author)

21 Laurentian University, Department of Biology

22935 Ramsey Lake Road, Sudbury, Ontario, Canada P3E 2C6

23 pryser@laurentian.ca;

24 Phone: 17056751151 ext. 2353; Fax: 17056754859

25

26 


\section{Abstract}

28 Root turnover is an important contributor to ecosystem nutrient and carbon cycling, but

29 seasonal aspects of root mortality are not well known. This study tests the hypothesis that

30 in strongly seasonal climates, such as in Northern Ontario, Canada, perennial wetland

31 monocots fall into two distinct categories with respect to their root overwintering

32 strategy: complete senescence, or survival over the winter. Root survival in late winter

33 and early spring was tested for a total of 26 species using vitality staining with

34 tetrazolium chloride (TTC). Root survival in spring was either over $85 \%$ (18 species), or

$350 \%$ (8 species). Lateral root survival was marginally lower than that of basal roots. In

36 some species low nutrient supply slightly increased root winter mortality, but did not

37 change the seasonal pattern. We conclude that in a northern temperate climate, the

38 overwintering strategies of roots of herbaceous monocots are binary: either avoidance or

39 tolerance of the long unfavourable season, similar to deciduous and evergreen leaves

40 among woody plants. Roots do not gradually die during the unfavourable season, but

41 either completely senesce in the autumn, or survive the winter. The distinct root

42 overwintering strategies presumably affect the species' resource economics and

43 ecosystem processes.

44

\section{$45 \quad$ Key words}

46 phenology, root mortality, root turnover, seasonal climate, wetland 


\section{Introduction}

49 Understanding the relationships between plant species' functional traits and their

50 ecological behaviour is necessary to predict species' responses to different environmental

51 conditions, and to be able to develop appropriate management practices under changing

52 environmental conditions (Aubin et al. 2016). Leaf life span is a central trait in this

53 context, with a major contribution to the species' position along the resource economics

54 spectrum, ranging from acquisitive to conservative strategies (Wright et al. 2004; Shipley

55 et al. 2006; Poorter et al. 2014). The role of the life span of roots, which in many

56 ecosystems compose more than half of primary production, is less known (Finzi et al.

57 2015; Iversen et al. 2015). Below-ground traits do not necessarily mirror the leaf

58 economics spectrum (Weemstra et al. 2016), and seasonal patterns of root production can

59 markedly differ from those observed above ground (Steinaker et al. 2010; Abramoff and

60 Finzi 2015; Blume-Werry et al. 2016; Schwieger et al. 2018). Lack of knowledge of fine

61 root phenology limits our understanding of the relationship between root turnover

62 strategies and environmental conditions (Radville et al. 2016).

63 Above-ground, the overwintering strategy of tree leaves in northern temperate

64 climate is a binary trait - deciduous or evergreen - and it is an important characteristic in

65 determining seasonal aspects of species' resource acquisition and loss (Walters and Reich

66 1999; Givnish 2002). A tradeoff between winter-hardiness and high photosynthetic

67 capacity of the leaves constrains a species' response to climate (Reich et al. 1998;

68 Kikuzawa and Lechowicz 2011). Below-ground, interspecific variation in root life span is

69 usually considered to be a continuous variable. However, for herbaceous wetland species

70 in climates with a long cold season there is evidence that root winter survival may be 
71 classified in two distinct categories. For example, roots of arctic wetland graminoids

72 mostly survive for several years, but Eriophorum species in the same environment renew

73 their root systems annually (Shaver and Billings 1975). Of the six northern Ontario

74 wetland graminoids studied by Ryser and Kamminga (2009), five had roots which did not

75 senescence at the end of the growing season, while roots of Sparganium americanum

76 completely senesced before the onset of winter.

77 In the present study we address the question whether root overwintering strategies

78 among perennial deciduous wetland monocots in climates with long and cold winters,

79 such as Northern Ontario, are of a binary nature in general. We hypothesize that roots of

80 a given species either completely senescence before or over the long winter, or mostly

81 survive. Hence, as trees in such a climate can be classified either as deciduous or

82 evergreen, wetland monocots might be classified into two distinct categories based on

83 their root winter survival, either as species with "deciduous roots" or species with

84 "evergreen roots". Existence of two contrasting root overwintering strategies among these

85 herbaceous species that all have autumn-senescing leaves would further emphasize

86 differences between plant above-ground and below-ground economic strategies.

87 We limit the study to monocotyledons, as their root systems show no secondary

88 growth and less structural and architectural variation than roots of dicotyledonous

89 species. Monocots also are the dominant growth form in a majority of open wetlands in

90 the region (Harris et al. 1996). The species were selected due to their commonness,

91 representing a variety of different taxonomic groups and wetland types. 
92 We also addressed the questions of whether the nutritional status of a plant

93 influences root winter survival, and whether there is a difference in senescence patterns

94 between basal and lateral roots.

95

\section{Materials and Methods}

$97 \quad$ Study area

98 The study area is located towards the northern limit of the deciduous zone (Rowe

99 1972). Sudbury has on average a growing season of 125-145 days, defined as the period

100 between the last and first frost (OMAFRA 2016). The annual average temperature is

$1014.1^{\circ} \mathrm{C}$, with daily averages of $-13^{\circ} \mathrm{C}$ in January, and $19.1^{\circ} \mathrm{C}$ in July. The average

102 minimum temperature in January is $-17.9^{\circ} \mathrm{C}$, the average maximum in July $24.8^{\circ} \mathrm{C}$

103 (Environment and Climate Change Canada 2017). In the region, wetland monocots

104 generally become photosynthetic in late May, and their leaves senesce between

105 September and November, depending on species (P. Ryser, personal observation). Hence,

106 for many species the period without photosynthesis is well over six months.

107 Soil temperatures at $5 \mathrm{~cm}$ and $30 \mathrm{~cm}$ depths have been measured in 38 wetlands of

108 the region over the winter 2012-2013 (iButton® DS1921G-F5\# data loggers; Maxim

109 Integrated, San Jose, USA). The soil did not freeze in any of those wetlands, despite

110 minimum air temperatures of below $-40^{\circ} \mathrm{C}$, probably as a result from the insulating snow

111 cover and litter layer and often, flowing water (P. Ryser, unpublished data).

112

113 Overview of the measurements and growth conditions 
114 Root winter mortality was tested for 26 perennial wetland monocot species of

115 Northeastern Ontario (Table 1). The plants were grown in mesocosms in an experimental

116 garden, and assessed for their winter root mortality after one or two years of growth.

117 These measurements occurred over 10 years and consist of two main parts. In 2007 and

118 2008, root winter mortality was assessed in an experiment for eight species with

119 successive collections over the entire winter, either from November to March (A; Table

120 1), or from January to early April (B; Table 1). The plants were grown with two different

121 nutrient supply rates. One additional species with two collected individuals was tested as

122 well. In 2013-2017, root winter mortality was screened for 20 species by testing the

123 proportion of living and dead roots at the end of the winter, before new growth started in

124 the spring. These plants were grown without further nutrient additions. For 16 of these

125 species root mortality was assessed for proximal and distal roots separately (C; Table 1),

126 and for four species it was assessed for all roots together (D; Table 1). Three of the

127 species were investigated in both 2007-2008 and 2013-2017.

128 The plants were grown in 10-litre mesocosms filled with wetland topsoil from a

129 beaver meadow with $\mathrm{pH} 4.0$ and organic matter content of $26 \%$ (Bainbridge construction,

130 North Bay, Ontario). The mesocosms stood in pools filled with ground water about $20 \mathrm{~cm}$

131 deep, with substrate surface 2-5 centimeters above the water. The plants assessed in

132 2007-2008 were grown for two growing seasons before assessing the percentage of living

133 and dead roots during the winter. The plants screened in 2013-2017 were grown for one

134 growing season and one winter before the measurement. During winter, all plants were

135 protected from freezing by covering them with $20-30 \mathrm{~cm}$ of straw and tarpaulins. The

136 overwintering plants did not experience temperatures below zero. 
138 The experiments and studied species

139 The measurements in the winter 2007-2008 to assess root winter mortality was

140 conducted for two species of Poaceae (Calamagrostis canadensis (Michx.) P.Beauv. and

141 Glyceria canadensis (Michx.) Trin.), and two Scirpus species (S. cyperinus (L.) Kunth.

142 and S. microcarpus J. Presl \& C. Presl) by harvesting 10-11 plants at 1-2 week intervals

143 from November 8 to March 24, and for four species of Carex (C. lacustris Willd., C.

144 magellanica Lam., C. oligosperma Michx., C. stricta Lam.) by harvesting 8 plants at 1-2

145 week intervals from January 8 to April 1. Each harvest lasted for several days due to the

146 time-consuming careful washing out of the roots. In addition, root vitality was assessed

147 for two individual plants of a fifth Carex species, C. aquatilis Wahlenb. in early January,

148 one plant in each nutrient treatment. Data of this species are shown, but not included into

149 the statistical analyses. After collecting plants from their winter storage under snow and

150 straw, the plants were kept outdoors in an insulated box until processing. Substrate

151 temperatures during this storage remained mostly above zero, except for February and

152 March when the soil in some pots froze to temperatures a few degrees below zero.

153 These plants were subjected to two levels of nutrient additions from May to

154 September during two growing seasons, 2006 and 2007, with weekly additions of $250 \mathrm{ml}$

155 of nutrient solution per mesocosm, containing either high or low concentration of mineral

156 nutrients. The high-level nutrient solution consisted of $17 \mathrm{mM} \mathrm{N}, 7.6 \mathrm{mM} \mathrm{P}, 6.0 \mathrm{mM} \mathrm{K}$,

$1570.9 \mathrm{mM} \mathrm{Mg}, 0.9 \mathrm{mM} \mathrm{S}, 1.8 \mathrm{mM} \mathrm{Ca}, 21 \mu \mathrm{M} \mathrm{Fe}, 9 \mu \mathrm{M} \mathrm{Cu}, 9 \mu \mathrm{M} Z \mathrm{Zn}, 22 \mu \mathrm{M} \mathrm{B}, 0.06 \mu \mathrm{M}$

158 Mo and $11 \mu \mathrm{M}$ Mn. The low-level nutrient solution was one tenth of that strength. As an 
159 indicator for the effect of nutrient treatments, at harvest the total root dry mass was

160 measured after drying for at least 72 hours at $75^{\circ} \mathrm{C}$.

161 Between 7 May and 21 May 2013, root mortality was assessed for 16 monocot

162 species collected in the region of Sudbury in spring and early summer 2012: Alisma

163 triviale Pursh, Calla palustris L., Carex oligosperma, Carex stricta, Carex utriculata

164 Boott, Dulichium arundinaceum (L.) Britton, Eleocharis palustris (L.) Roem. \& Schult., 165 Juncus brevicaudatus (Engelm) Fernald, Juncus tenuis Willd., Pontederia cordata L.,

166 Rhynchospora alba (L.) Vahl, Sagittaria latifolia Willd., Schoenoplectus acutus

167 (Bigelov) Á. Löve \& D. Löve, Scirpus microcarpus, Sparganium americanum Nutt.,

168 Typha latifolia L. In early May 2015, root mortality was assessed for Carex lasiocarpa

169 Ehrh. and Rhynchospora fusca (L.) W.T. Aiton, originating from Lake Superior

170 Provincial Park (300 km west of Sudbury) and grown in the experimental mesocosms in

171 the experimental garden since spring 2014. In contrast to all previously studied species,

172 these two species grew on sieved artificial blend of loam, peat moss and compost

173 (President's Choice® Black Earth Topsoil; Brampton, Loblaws, Canada). In April 2017,

174 root mortality was assessed for Triglochin maritima L. originating from Foleyet (ON,

175 Canada) and Triglochin palustris L., originating from Manitoulin Island (ON, Canada),

176 after one year of growth in the mesocosms on a mixture of $20 \%$ of the artificial topsoil

177 blend and $80 \%$ sand.

179 Assessment of root survival and mortality

180 The death of a root is not visible until decomposition processes start. In order to

181 detect root mortality immediately after death we used vital staining with 2,3,5- 
182 triphenyltetrazolium-chloride (TTC) solution (Comas et al. 2000). The samples were

183 incubated in $25 \mathrm{ml}$ vials in a solution of $0.3 \%$ TTC and $10 \mathrm{mM}$ glucose for 48 hours at

$18430^{\circ} \mathrm{C}$ in total darkness. The colorless TTC functions as an $\mathrm{H}$-acceptor in living cells,

185 producing insoluble red-coloured 2,3,5-triphenylformazan, which can be used as an

186 indication of root viability (Comas et al. 2000). The glucose provides additional substrate

187 for the metabolism, enhancing the coloration in substrate-limited cells (Collet et al.

188 2002). As the colour of roots considerably varies among the species, for most of the

189 species the colour of the investigated roots was compared with that of roots killed by

190 heating them to $70^{\circ} \mathrm{C}$ before staining. The heated roots did not develop any red or pink

191 colour, a clear indicator that roots staining red were alive. The degree of redness varied

192 among the species, but any distinct sign of red colour in cortex or stele was interpreted as

193 the root being alive.

194 For the experiment in 2007-2008, samples of coarse basal roots and fine lateral

195 roots were collected separately. Fifty to two hundred randomly selected $10 \mathrm{~mm}$ pieces of

196 basal roots were collected close to the stem base, and five randomly selected samples of

197 lateral roots, approximately $1 \mathrm{~g}$ each, were collected at different parts of the root system.

198 For plants screened in 2013, two samples were collected at different depths as $1 \mathrm{~cm}$-wide

199 cross sections across the entire root systems. One of the samples was collected $1 \mathrm{~cm}$

200 below the stem (proximal sample), consisting mostly of coarse basal roots, the other 12

201 cm below the stem (distal sample) consisting of some basal and mostly lateral roots.

202 Fine root viability was quantified using the grid-intersection method (Newman

203 1966; Tennant 1975) in a 140 mm Petri dish with help of a hand-held magnifier (3×).

204 Percentage of basal roots alive was assessed by counting the number of stained pieces of 
205 basal roots as a percentage of the total number of pieces of basal roots in the sample. If no 206 stain could be seen with the magnifier, the samples were observed with a stereo

207 microscope $(35 \times)$. The rhizodermis does not always allow penetration of TTC into the 208 root, and the section was considered to be alive even if the staining was limited to the 209 section close to the cut cross-sectional surface. In case of a dark rhizodermis, staining of 210 the stele, which usually was the most responsive part of the root to staining, was

211 determined after exposing it by peeling the rhizodermis away with fine forceps.

\section{Data analyses}

214 In the experiment of 2007-2008 the percentage of dead lateral root length, and root 215 dry mass was analysed using a General Linear model with species, nutrient treatment and 216 their interaction as independent factors. The percentage of dead root length was arcsine

217 Box-Cox-transformed to attain normal distribution. The effect of the time of harvest on

218 lateral root mortality was tested with the same model, but adding the date of harvest as a

219 continuous independent variable. Due to the high number of plants with close to $100 \%$ of

220 living basal roots, the data on basal root mortality could not be normalized. Hence,

221 statistical analyses for the effect of nutrient supply on root mortality were conducted

222 using Kruskal-Wallis tests. The effect of nutrients was tested separately for each species,

223 and the effect of species separately for each nutrient supply level. Differences between

224 percentages of basal and lateral root mortality were tested with Wilcoxon signed-rank 225 tests for each species separately. For the data of 2013, the effect of the two sampling

226 positions along the root system on the same individuals - proximal and distal to the stem

227 - on arcsine-transformed root mortality was analysed with a repeated measures ANOVA 
228 with the position as a within-subject factor and the species as an independent between-

229 subject factor.

\section{$231 \quad$ Results}

232 All the species investigated in 2007-2008 had a high percentage of surviving root

233 length, both for lateral and basal roots (Fig. 1). Lateral roots had a slightly lower survival

234 than basal roots in case of Calamagrostis canadensis and Glyceria canadensis, but even

235 for these species the difference between the two root categories remained well below

$23610 \%$ (Fig. 1; Table 2). Species effect was significant on lateral root survivorship (Table

237 3), which for Calamagrostis canadensis was $85 \%$ and for G. canadensis 89\%, while all

238 the Cyperaceae species had on average a root survival of above 98\%. Species effect on

239 basal root survival was significant only at low nutrient supply (Supplementary Material,

240 Table $S 1^{1}$ ). The percentage of living roots did not decrease over the winter for any of the

241 species, and the effect of date of harvest on root survival was not significant (Table 3).

242 Nutrient treatment had a clear effect on plant size, root dry mass in the high nutrient

243 treatment being 2-3 times higher than in the low nutrient treatment (Fig. 2;

244 Supplementary Material, Table S2). Nutrient effect on lateral root survival was

245 significant albeit small, with values at the low nutrient supply 5-7\% lower for the two

246 grass species and with less than $1 \%$ difference for all the Cyperaceae (Fig. 1, Table 3).

247 Species $\times$ Nutrient interaction was not significant (Table 3). Basal root survival was not

248 affected by nutrient supply for any of the species $(p>0.250$; Fig. 1; Supplementary

249 Material, Table S3).

\footnotetext{
${ }^{1}$ Supplementary data are available with the article through the journal Web site at http://nrcresearchpress.com/doi/suppl/10.1139/cjb-2018-0065.
} 
For the species assessed in 2013-2017, the percentage of roots that stained red in

251 spring was either above $85 \%$ or close to zero (Fig. 3). Calla palustris, $P$. cordata and $R$.

252 alba had no surviving roots at all, and A. triviale, Sagittaria latifolia and Sparganium

253 americanum had less than 3\% of their roots alive in May. For the latter three species a

254 few vigorous, bright white, obviously newly produced roots were observed, indicating

255 that the few roots staining red with TTC in May were the first roots of the new cohort

256 produced early that spring. It is unlikely that these few stained roots had survived over

257 the winter. Nevertheless, for all plants with a complete root winter mortality the rhizomes

258 or other storage organs stained red in spring, indicating that the plants were alive. For all

259 these species individuals not destroyed at harvest continued growing in the following

260 growing season.

261 For the ten species with a separate assessment of root mortality in proximal and

262 distal samples in 2013, and with the roots mostly surviving the winter, the percentage of

263 living roots was higher when collected $1 \mathrm{~cm}$ below the stem base than $12 \mathrm{~cm}$ below it.

264 Difference in average survival between the two different root positions was small, $96.2 \%$

265 vs. 94.8\%, but significant (Table 4). The extent of root survival significantly varied

266 among the species, being for Carex oligosperma and C. stricta below $93 \%$ while the

267 other species had higher values. Species $\times$ position interaction was significant due to the

268 relatively large difference in survival between the root positions for $C$. utriculata, with

$26986 \%$ and 99\% (Fig 3; Table 4).

270

271 Discussion 
The data support our hypothesis that in a climate with a severe and long winter,

273 wetland monocots can be divided into two distinct categories with respect to their root

274 winter mortality, comparable to evergreen and deciduous habits among trees. Roots either

275 mostly survive the winter, or completely senesce. In the case of species with

276 overwintering roots, average survival was in almost all cases over $90 \%$ of the total root

277 length, and never below 85\%. The measurements for different species were conducted

278 over several years with some variation in nutrient availability and the procedure of root

279 sampling, but overall, the effects of the year, nutrient supply, type of substrate or root

280 order and position within the root system were minor compared to the clear species-

281 specific binary distinction. Species that were measured in different experimental setups

282 showed consistent behaviour. Furthermore, for several of the species data exist to confirm

283 their either complete root senescence before the winter, or survival of the majority of the

284 roots over the winter: Carex aquatilis, C. oligosperma, C. stricta, R. alba, Sagittaria

285 latifolia, Scirpus microcarpus and Sparganium americanum (Shaver and Billings 1975;

286 Ohlson and Malmer 1990; Ryser and Kamminga 2009; Lawrence et al. 2013; Alsahame

287 2016). These data support our conclusions that root winter survival among perennial

288 temperate wetland monocots is a binary species-specific trait, similar to leaf winter

289 survival in temperate trees. The rate of senescence and mortality rate over the winter may

290 be modified by environmental conditions, but the binary nature of the root survival

291 strategy remains unchanged.

292 For the species measured during the entire winter, there was no sign of increasing

293 mortality over the winter. Measurements of root mortality in autumn show that roots of

294 species with complete mortality at the end of the growing season such as Sparganium 
295 americanum, Sagittaria latifolia and R. alba, have already senesced by October and

296 November (Ryser and Kamminga 2009; Alsahame 2016). Their early senescence

297 indicates that the mortality is a result of an active senescence as preparation for the

298 oncoming winter, rather than a result of extreme conditions during the winter,

299 comparable to leaf senescence of deciduous trees (Kim et al. 2016). All the investigated

300 species are deciduous perennials, as they overwinter with vegetative tissues, but lose their

301 leaves for the winter. Root survival over the winter in the majority of the species, despite

302 autumn-senescing leaves in all of them, further emphasizes that above-ground data alone

303 is not sufficient to describe ecosystem carbon cycling (Abramoff and Finzi 2015).

304 Several of the species which had both leaves and roots senescing, such as R. alba,

305 Sagittaria latifolia, and T. palustris, can be considered to be functional annuals (Verburg

306 and During 1998), as the overwintering vegetative organ is relatively small and may

307 serve as a propagule potentially aiding in dispersal.

308 Interspecific variation in root life span is assumed to be associated with species'

309 resource economics: fast-growing roots maximize resource acquisition but have a short

310 life-span, while long-lived roots grow slowly but maximize resource conservation (Ryser

311 1996; Roumet et al. 2016). Short-lived roots are often associated with species of

312 disturbed and nutrient-rich habitats (Roumet et al. 2016); of the species in the present

313 study A. triviale is such a species (Hood 2013). On the other hand, for many of the

314 species the ecological advantage of annually renewed roots is not obvious. Sparganium

315 americanum, $P$. cordata, or Sagittaria latifolia form stable stands on sheltered and

316 infrequently disturbed shores (Hall and Penfound, 1943; Keddy, 1983; Souch et al.,

317 1998), and Eriophorum species with annually renewed root systems are dominant of 
318 many arctic wetlands (Shaver and Billings 1975). Rhynchospora alba grows on nutrient-

319 poor sites with otherwise sparse vascular plant vegetation (Ohlson and Malmer 1990).

320 The binary nature of the winter survival of leaves and roots, however, goes beyond

321 being positions along a continuous gradient of life span. It is not clear what trade offs

322 lead to the binary nature of root winter survival, but it is possible that capacity of roots to

323 survive the unfavourable season restricts their growth response to favourable conditions,

324 in a similar manner to leaves. Deciduous leaves are more efficient in resource acquisition,

325 i.e., photosynthesis, during the favourable season (Reich et al. 1998), while evergreen

326 leaves, able to tolerate freezing temperatures, are more efficient in resource conservation

327 and better able to take advantage of marginal seasons (Givnish 2002). However,

328 temperatures in wetland soils in the study area usually remain above $0^{\circ} \mathrm{C}$ during the

329 winter (unpublished data, P. Ryser), which means that the risk of frost damage to roots in

330 wetland soils at least in the study region is small. Soil nutrient availability in seasonal

331 wetlands can show a distinct peak in early spring (Edwards and Jefferies 2010), and

332 species with overwintering roots may be better able to utilize such short-term resources.

333 Growth at low nutrient availability slightly increased root winter mortality, but this did

334 not change the general species-specific pattern. Previous investigations on nutrient effects

335 on root life span show inconsistent results: nutrient addition either increases or decreases

336 root life span, or has no effect (McCormack and Guo 2014).

337 Our data is not conclusive about the actual life span of winter-surviving roots.

338 Survival over one winter does not mean that an organ would live for several years,

339 illustrated by leaves of several ericaceous dwarf shrubs of northern nutrient poor

340 wetlands which senesce during their second growing season while nutrients in them are 
341 being remobilized for new growth (Reader 1978). Nevertheless, roots of several arctic

342 graminoid species are known to live for 6-8 years (Shaver and Billings 1975). The low

343 percentages of dead roots (often <2\%) found in the present study for Scirpus and Carex

344 species that had been growing for two growing seasons in the mesocosms indicate that

345 roots of these species survive at least for two winters. Decomposition could have reduced

346 this percentage of dead roots observed after a second growing season, but it seems

347 unlikely that the thick and robust basal roots of these species would disappear without

348 trace so quickly under the water-logged conditions. Survival rates of lateral roots and

349 basal roots hardly differed, matching the modular structure of monocotyledonous root

350 systems, comprised of numerous adventitious roots (Fitter 1987), and indicates that root

351 turnover happens module by module, in contrast to trees in which fine roots generally

352 show a shorter life span than coarse roots (Wells and Eissenstat 2001). Our measurements

353 were conducted over several years, but the data is very consistent, root winter survival of

354 the species was either over $85 \%$ or $0 \%$. The three species which were assessed twice

355 showed similar results in both occasions.

356 In conclusion, the results show that root turnover among wetland graminoids - in a

357 similar manner to leaf turnover - is a part of a plant's development and the species'

358 adaptive strategy. Roots do not just die of wear and tear, but their mortality is an active

359 response to seasonal pattern of the climate with an adaptive choice - at an evolutionary

360 time scale - between avoidance and tolerance. Roots do not gradually die during the

361 winter: they either senesce in the autumn in a controlled manner, or they mostly survive

362 the winter. This choice is bound to have significant consequences for the species'

363 resource economics, contributing to its performance in different environments and to 
364 seasonal patterns of ecosystem nutrient and carbon dynamics. Constraints underlying the

365 trade off between root tolerance or avoidance of the cold season remain unknown, and

366 further research is needed to understand to which extent these binary strategies in root

367 turnover can be found under different climatic conditions.

\section{Acknowledgements}

370 We are grateful to Bonnie Matthews, Jamie Montgomery, Tarra Degazio and Kathleen

371 Côté for their contributions to collecting the experimental plants from the field, and for

372 Aurèle Beaulieu, Émile Mainville and Frank Mallory for their generous support of the

373 experimental garden. The research was supported by a Natural Sciences and Engineering

374 Research Council of Canada Discovery Grant to PR (Grant number 249689). The stay of

375 TN and YH in Sudbury was enabled by the exchange program 'Promoting Environmental

376 Management Awareness: A Transatlantic Perspective' between the European Union and 377 Canada.

\section{References}

380 Abramoff, R.Z., and Finzi, A.C. 2015. Are above- and below-ground phenology in sync?

$381 \quad$ New Phytol. 205(3): 1054-1061. DOI: 10.1111/nph.13111.

382 Alsahame, M. 2016. Protein content and protease activity in senescing roots and leaves of

383 wetland monocot species with contrasting root turnover strategies. M.Sc. thesis,

384 Department of Biology, Laurentian University, Sudbury, ON, Canada.

385 https://zone.biblio.laurentian.

386 ca/bitstream/10219/2562/1/Thesis\%20Alsahame\%20Final.pdf. 
387

388

389

390

391

392

393

394

395

396

397

398

399

400

401

402

403

404

405

406

407

408

409

Aubin, I., Munson, A.D., Cardou, F., Burton, P.J., Isabel, N., Pedlar, J.H., Paquette, A., Taylor, A.R., Delagrange, S., Kebli, H., and Messier, C. 2016. Traits to stay, traits to move: a review of functional traits to assess sensitivity and adaptive capacity of temperate and boreal trees to climate change. Environ. Rev. 24(2): 164-186. https://doi.org/10.1139/er-2015-0072.

Blume-Werry, G., Wilson, S.D., Kreyling, J., and Milbau, A. 2016. The hidden season: growing season is 50\% longer below than above ground along an arctic elevation gradient. New Phytol. 209(3): 978-986. DOI: 10.1111/nph.13655.

Collet, L., de Leon, C., Kollmeier, M., Schmohl., N, and Horst., WJ. 2002. Assessment of aluminum sensitivity of maize cultivars using roots of intact plants and excised root tips. J. Plant Nutr. Soil Sci. 165(3): 357-365. DOI: 10.1002/15222624(200206)165:3<357::AID-JPLN357>3.0.CO;2-V.

Comas, L.H., Eissenstat, D.M., and Lakso, A.N. 2000. Assessing root death and root system dynamics in a study of grape canopy pruning. New Phytol. 147(1): 171178. DOI: 10.1046/j.1469-8137.2000.00679.x.

Edwards, K.A., Jefferies, R.L. 2010. Nitrogen uptake by Carex aquatilis during the winter-spring transition in a low Arctic wet meadow. J. Ecol. 98(4): 737-744. DOI: 10.1111/j.1365-2745.2010.01675.x.

Environment and Climate Change Canada. 2017. 1981-2010 Climate Normals [Online]. Available from: http://climate.weather.gc.ca/climate_normals/index_e.html. [accessed 9 June 2018].

Finzi, A.C. Abramoff, R.Z. Spiller, K.S. Brzostek, E.R., Darby, B.A., Kramer, M.A., and Phillips, R.P. 2015. Rhizosphere processes are quantitatively important components 
410

411

412

413

414

415

416

417

418

419

420

421

422

423

424

425

426

427

428

429

430

of terrestrial carbon and nutrient cycles. Glob. Change Biol. 21(5): 2082-2094.

DOI: $10.1111 / \mathrm{gcb} .12816$.

Fitter, A.H. 1987. An architectural approach to the comparative ecology of plant root systems. New Phytol. 106(s1): 61-77. DOI: 10.1111/j.1469-8137.1987.tb04683.x.

Givnish, T.J. 2002. Adaptive significance of evergreen vs. deciduous leaves: solving the triple paradox. Silva Fenn. 36(3): 703-743. https://doi.org/10.14214/sf.535.

Hall, T.F., and Penfound, W.T. 1943. Cypress-gum communities in the Blue Girth swamp near Selma, Alabama. Ecology, 24(2): 208-217. DOI: 10.2307/1929701.

Harris, A.G., McMurray, S.C., Uhlig, P.W.C., Jeglum, J.K., Foster, R.F., and Racey, G.D. 1996. Field guide to the wetland ecosystem classification for Northwestern Ontario. Queen's Printer for Ontario, Canada.

Hood, W.G. 2013. Applying and testing a predictive vegetation model to management of the invasive cattail, Typha angustifolia L, in an oligohaline tidal marsh reveals priority effects caused by non-stationarity. Wetl. Ecol. Manage. 21(4): 229-242. https://doi.org/10.1007/s11273-013-9294-6.

Iversen, C.M., Sloan, V.L., Sullivan, P.F., Euskirchen, E.S., McGuire, A.D., Norby, R.J., Walker, A.P., Warren, J.M., and Wullschleger, S.D. 2015. The unseen iceberg: plant roots in arctic tundra. New Phytol. 205(1): 34-58. DOI: 10.1111/nph.13003.

Keddy, P.A. 1983. Shoreline vegetation in Axe Lake Ontario: effects of exposure on zonation patterns. Ecology, 64(2): 331-344. DOI: 10.2307/1937080.

Kikuzawa, K., and Lechowicz, M.J. 2011. Ecology of leaf longevity. Springer, Tokyo. 
431 Kim, J., Woo, H.R. and Nam, H.G., 2016. Toward systems understanding of leaf

432

433

434

435

436

437

438

439

440

441

442

443

444

445

446

447

448

449

450

451

452

453

senescence: an integrated multi-omics perspective on leaf senescence research. Molecular Plant, 9(6): 813-825. http://dx.doi.org/10.1016/j.molp.2016.04.017.

Lawrence, B.A., Fahey, T.J., and Zedler, J.B. 2013. Root dynamics of Carex strictadominated tussock meadows. Plant and Soil, 364(1-2): 325-339. https://doi.org/10.1007/s11104-012-1360-y.

McCormack, M.L. and Guo, D. 2014. Impacts of environmental factors on fine root lifespan. Front. Plant Sci. 5(205) 1-11. https://doi.org/10.3389/fpls.2014.00205.

Newman, E.I., 1966. A method of estimating the total length of root in a sample. J. Appl. Ecol. 3(1): 139-145.

Ohlson, M. and Malmer N. 1990. Total nutrient accumulation and seasonal variation in resource allocation in the bog plant Rhynchospora alba. Oikos, 58(1): 100-108. DOI: $10.2307 / 3565365$.

OMAFRA (Ontario Ministry of Agriculture, Food and Rural Affaris) 2016. Climate zones and planting dates for vegetables in Ontario. Queen's Printer for Ontario [Online]. Available from:

http://www.omafra.gov.on.ca/english/crops/facts/climzoneveg.htm [accessed 9 June 2018].

Poorter, H., Lambers, H., and Evans, J.R. 2014. Trait correlation networks: a whole-plant perspective on the recently criticized leaf economic spectrum. New Phytol. 201(2): 378-382. DOI: $10.1111 / \mathrm{nph} .12547$.

Radville, L., McCormack, M.L., Post, E., and Eissenstat, D.M. 2016. Root phenology in a changing climate. J. Exp. Bot. 67(12): 3617-3628. doi:10.1093/jxb/erw062 
454 Reader, R.J. 1978. Contribution of overwintering leaves to the growth of three broad455 leaved, evergreen shrubs belonging to the Ericaceae family. Can. J. Bot. 56(10): 1248-1261. https://doi.org/10.1139/b78-139.

Reich, P.B., Ellsworth D.S., and Walters M.B. 1998. Leaf structure (specific leaf area) modulates photosynthesis-nitrogen relations: evidence from within and across species and functional groups. Funct. Ecol. 12(6): 948-958. DOI: 10.1046/j.1365-

Roumet, C., Birouste, M., Picon-Cochard, C., Ghestem, M., Osman, N., Vrignon-Brenas, S., Cao, K.F., and Stokes, A. 2016. Root structure-function relationships in 74 species: evidence of a root economics spectrum related to carbon economy. New Phytol. 210(3): 815-826. DOI: 10.1111/nph.13828.

465 Rowe, J.S. 1972. Forest regions of Canada. Canadian Forestry service. Department of the 466 Environment. Ottawa, Canada. http://cfs.nrcan.gc.ca/pubwarehouse/pdfs/24040.pdf.

467 Ryser, P., and Kamminga, A.T. 2009. Root survival of six cool-temperate wetland 468 graminoids in autumn and early winter. Plant Ecol. Divers. 2(1): 27-35. 469 https://doi.org/10.1080/17550870802609630.

470 Ryser, P. 1996. The importance of tissue density for growth and life span of leaves and 471 roots: a comparison of five ecologically contrasting grasses. Funct. Ecol. 10(6): 472 717-723. DOI: $10.2307 / 2390506$.

473 Shaver, G.R., and Billings, W.D. 1975. Root production and root turnover in a wet tundra 474 ecosystem, Barrow, Alaska. Ecology, 56(2): 401-409. DOI: 10.2307/1934970.

475 Schwieger, S., Kreyling, J., Milbau, A. and Blume-Werry, G. 2018. Autumnal warming 476 does not change root phenology in two contrasting vegetation types of subarctic 
477

478

479

480

481

482

483

484

485

486

487

488

489

490

491

492

493

494

495

496

497

498

499

tundra. Plant and Soil, 424(1-2): 145-156. https://doi.org/10.1007/s11104-017$3343-5$.

Shipley, B., and Lechowicz, M.J., Wright I., Reich P.B. 2006. Fundamental trade-offs generating the worldwide leaf economics spectrum. Ecology, 87(3): 535-541. DOI: $10.1890 / 05-1051$.

Souch, C., Grimmond, C.S.B., and Wolfe C.P. 1998. Evapotranspiration rates from wetlands with different disturbance histories: Indiana Dunes National Lakeshore. Wetlands, 18(2): 216-229. https://doi.org/10.1007/BF03161657.

Steinaker, D.F., Wilson, S.D., and Peltzer, D.A. 2010. Asynchronicity in root and shoot phenology in grasses and woody plants. Glob. Change Biol. 16(8): 2241-2251. DOI: $10.1111 / j .1365-2486.2009 .02065 . x$.

Tennant, D. 1975. A test of a modified intersect method of estimating root length. J. Ecol. 63(3): 995-1001. https://doi.org/10.2307/2258617

Verburg, R.W. and During, H.J. 1998. Vegetative propagation and sexual reproduction in the woodland understorey pseudo-annual Circaea lutetiana L. Plant Ecol. 134(2), 211-224. https://doi.org/10.1023/A:1009741102.

Walters, M.B., and Reich, P.B. 1999. Low-light carbon balance and shade tolerance in the seedlings of woody plants: do winter deciduous and broad-leaved evergreen species differ? New Phytol. 143(1): 143-154. DOI: 10.1046/j.14698137.1999.00425.x.

Weemstra, M., Mommer, L., Visser, E.J., Ruijven, J., Kuyper, T.W., Mohren, G.M., and Sterck, F.J. 2016. Towards a multidimensional root trait framework: a tree root review. New Phytol. 211(4): 1159-1169. DOI: 10.1111/nph.14003. 
500 Wells, C.E., and Eissenstat, D.M. 2001. Marked differences in survivorship among apple 501 roots of different diameters. Ecology, 82(3): 882-892.

502 Wright, I.J., Reich, P.B., Westoby, M., Ackerly, D.D., Baruch, Z., Bongers, F., Cavender503 Bares, J., Chapin, T., Cornelissen, J.H.C., Diemer, M., Flexas, J., Garnier, E., 504 Groom, P.K., Gulias, J., Hikosaka, K., Lamont, B.B., Lee, T., Lee, W., Lusk, C., 505 Midgley, J.J., Navas, M.-L., Niinemets, Ü., Oleksyn, J., Osada, N., Poorter, H., 506 Poot, P., Prior, L., Pyankov, V.I., Roumet, C., Thomas, S.C., Tjoelker, M.G., 507 Veneklaas, E.J., \& Villar, R. 2004. The worldwide leaf economics spectrum.

$508 \quad$ Nature, 428(6985): 821-827. doi:10.1038/nature02403. 509 


\section{$510 \quad$ Figure captions}

511 Fig. 1. Percentage of living root length (TTC staining) during the winter for lateral and

512 basal roots of eight wetland monocot species at two nutrient supply levels, investigated in

513 2007-2008. The two lighter bars to the left for each species show the data for fine lateral

514 roots, the two darker bars to the right the data for coarse basal roots. Within each pair, the

515 darker bar to the left show data at the high nutrient supply, the lighter one to the right at

516 the low nutrient supply. Species without asterisk were harvested between November and

517 March ( $n=9-11)$, species with asterisk between January and early April ( $n=8$, except for

518 C. aquatilis $n=1$ ). The bars represent mean values of all plants harvested in the respective

519 periods $( \pm 1 \mathrm{SE})$.

520

521 Fig. 2. Root dry mass during the winter for eight wetland monocot species at low (light

522 grey) and high (dark grey) nutrient supply levels, and harvested after two growing

523 seasons of growth in November-March (no asterisk; $n=9-11$ ) or in January-April

524 (asterisk; $n=8$, expect for $C$. aquatilis $n=1$ ). The bars represent mean values of all plants

525 harvested in the respective periods ( $\pm 1 \mathrm{SE})$.

526

527 Fig 3. Percentage of living root length (TTC staining) in early May of 16 wetland

528 monocot species. In 2013, the roots were collected either proximally $(1 \mathrm{~cm}$ below the

529 stem; filled bars) or distally (12 cm below the stem; open bars). For the species with an

530 asterisk only one mixed sample (grey bars) per plant was collected in 2015 or 2017. $n=5$,

531 except for the Triglochin species with $n=3$. Mean values \pm 1 SE. 
Table 1. Species investigated in the experiments of this study with the number of replicate plants in each measurement. A) November 2007-March 2008 with two nutrient treatments. Separate analyses for lateral and basal roots. B) January 2007-April 2008 with two nutrient treatments. Separate analyses for lateral and basal roots. C) Early May 2013. Sampled proximally ( $1 \mathrm{~cm}$ below stem, mostly basal roots) and distally (12 cm below stem, mostly lateral roots). D) Early May 2016 or 2017, one sample per plant. All plants were grown in 10 litre mesocosms, either on natural wetland soil $(\mathrm{N})$ or commercially available growth substrate (CGS). The substrate for the two Triglochin species contained $80 \%$ sand. At harvest, A and B had grown in the mesocosms for two growing seasons, $\mathrm{C}$ and $\mathrm{D}$ for one growing season. All plants were propagated vegetatively from Northern Ontario populations. LSPP=Lake Superior Provincial Park.

\begin{tabular}{|c|c|c|c|c|c|c|c|}
\hline Species & Family & $\mathbf{A}$ & B & C & D & Substrate & Origin \\
\hline Alisma triviale & Alismataceae & & & 5 & & $\mathrm{~N}$ & Sudbury \\
\hline Calamagrostis canadensis & Poaceae & 9 & & & & $\mathrm{~N}$ & Sudbury \\
\hline Calla palustris & Araceae & & & 5 & & $\mathrm{~N}$ & Sudbury \\
\hline Carex aquatilis & Cyperaceae & & 1 & & & $\mathrm{~N}$ & Sudbury \\
\hline Carex lacustris & Cyperaceae & & 8 & & & $\mathrm{~N}$ & Sudbury \\
\hline Carex lasiocarpa & Cyperaceae & & & & 5 & CGS & LSPP/Manitoulin Island \\
\hline Carex magellanica & Cyperaceae & & 8 & & & $\mathrm{~N}$ & Sudbury \\
\hline Carex oligosperma & Cyperaceae & & & 5 & & $\mathrm{~N}$ & Sudbury \\
\hline Carex stricta & Cyperaceae & & & 5 & & $\mathrm{~N}$ & Sudbury \\
\hline Carex utriculata & Cyperaceae & & & 5 & & $\mathrm{~N}$ & Sudbury \\
\hline Dulichium arundinaceum & Cyperaceae & & & 5 & & $\mathrm{~N}$ & Sudbury \\
\hline Eleocharis palustris & Cyperaceae & & & 5 & & $\mathrm{~N}$ & Sudbury \\
\hline Glyceria canadensis & Poaceae & 11 & & & & $\mathrm{~N}$ & Sudbury \\
\hline Juncus brevicaudatus & Juncaceae & & & 5 & & $\mathrm{~N}$ & Sudbury \\
\hline Juncus tenuis & Juncaceae & & & 5 & & $\mathrm{~N}$ & Sudbury \\
\hline Pontederia cordata & Pontederiaceae & & & 5 & & $\mathrm{~N}$ & Sudbury \\
\hline Rhynchospora alba & Cyperaceae & & & 5 & & $\mathrm{~N}$ & Sudbury \\
\hline Rhynchospora fusca & Cyperaceae & & & & 5 & CGS & LSPP \\
\hline Sagittaria latifolia & Alismataceae & & & 5 & & $\mathrm{~N}$ & Sudbury \\
\hline Schoenoplectus acutus & Cyperaceae & & & 5 & & $\mathrm{~N}$ & Sudbury \\
\hline Scirpus cyperinus & Cyperaceae & 10 & & & & $\mathrm{~N}$ & Sudbury \\
\hline Scirpus microcarpus & Cyperaceae & 10 & & 5 & & $\mathrm{~N}$ & Sudbury \\
\hline Sparganium americanum & Typhaceae & & & 5 & & $\mathrm{~N}$ & Sudbury \\
\hline Triglochin maritima & Juncaginaceae & & & & 3 & Sand/CGS & Foleyet \\
\hline Triglochin palustris & Juncaginaceae & & & & 3 & Sand/CGS & Manitoulin Island \\
\hline Typha latifolia & Typhaceae & & & 6 & & $\mathrm{~N}$ & Sudbury \\
\hline
\end{tabular}


Table 2. Results of Wilcoxon signed ranks tests on the difference in percentage of living root length between basal and lateral roots of eight wetland monocot species in the winter 2007-2008. Significant $p$-values $(p<0.050)$ in bold.

\begin{tabular}{lccc}
\hline & $n$ & $Z$-score & $p$ \\
\hline Carex lacustris & 16 & 0.104 & 0.918 \\
Carex magellanica & 16 & 0.879 & 0.379 \\
Carex oligosperma & 15 & -1.70 & 0.088 \\
Carex stricta & 16 & 0.83 & 0.406 \\
Calamagrostis canadensis & 18 & 3.29 & $\mathbf{0 . 0 0 1}$ \\
Glyceria canadensis & 22 & 2.16 & $\mathbf{0 . 0 3 1}$ \\
Scirpus cyperinus & 19 & -0.80 & 0.421 \\
Scirpus microcarpus & 20 & -1.53 & 0.126 \\
\hline
\end{tabular}


Table 3. Results of General Linear Models on the percentage of living lateral root length in the winter 2007-2008 for eight wetland monocot species, with species, and nutrient supply during growing season as independent factors (Model 1). Model 2 additionally includes the date of harvest as a continuous independent variable to test for a possible trend over time. Significant $p$-values $(p<0.050)$ in bold.

\begin{tabular}{|c|c|c|c|c|c|c|}
\hline & \multicolumn{3}{|c|}{ Model $1 ; r^{2}=0.508$} & \multicolumn{3}{|c|}{ Model $2 ; r^{2}=0.508$} \\
\hline & $\overline{\mathrm{df}}$ & $\bar{F}$ & $\bar{p}$ & $\overline{\mathrm{df}}$ & $F$ & $p$ \\
\hline Species & 7 & 17.4 & $<0.001$ & 7 & 16.3 & $<0.001$ \\
\hline Nutrients & 1 & 4.7 & 0.032 & 1 & 4.7 & 0.033 \\
\hline Species $\times$ Nutrients & 7 & 0.4 & 0.884 & 7 & 0.4 & 0.884 \\
\hline Date & - & - & - & 1 & 0.0 & 0.857 \\
\hline
\end{tabular}


Table 4. Results of the repeated measures ANOVA on percentage of root length alive after the winter in early May 2013. Ten species with the majority of their roots surviving the winter are included in the analysis. Arcsine transformed percentage of alive roots as the independent variable, species as dependent factor, and the position of the root sample $(1 \mathrm{~cm}$ and $12 \mathrm{~cm}$ below the stem) as repeated within-subjects factor. $n=51$. Significant $p$ values $(p<0.050)$ in bold.

df $F \quad p$

Between subjects

Species

$9 \quad 5.0<\mathbf{0 . 0 0 1}$

Within subjects

Position of root sample $1 \quad 13.3 \quad<\mathbf{0 . 0 0 1}$

Species $\times$ Position $\quad 9 \quad 7.4 \quad<\mathbf{0 . 0 0 1}$ 


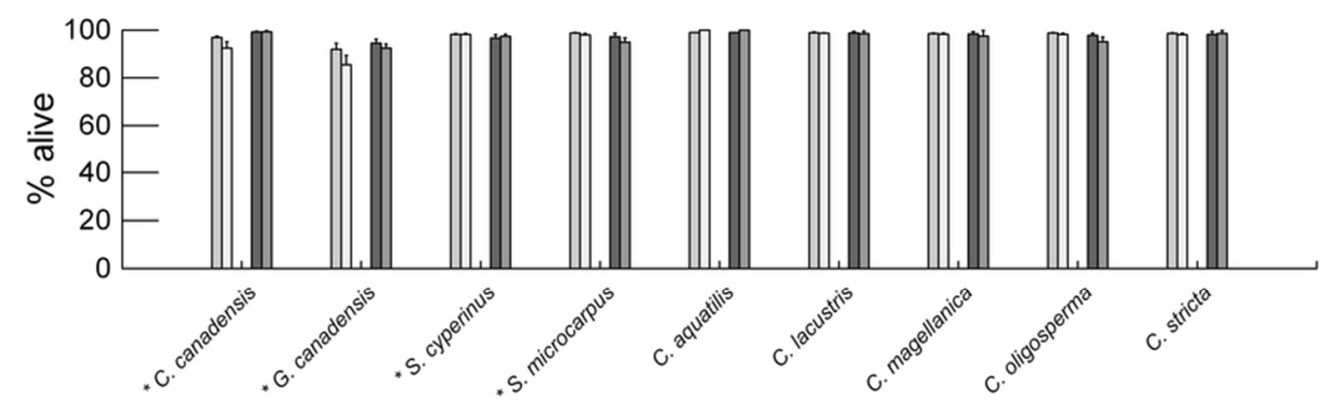

Fig. 1. Percentage of living root length (TTC staining) during the winter for lateral and basal roots of eight wetland monocot species at two nutrient supply levels, investigated in 2007-2008. The two lighter bars to the left for each species show the data for fine lateral roots, the two darker bars to the right the data for coarse basal roots. Within each pair, the darker bar to the left show data at the high nutrient supply, the lighter one to the right at the low nutrient supply. Species without asterisk were harvested between November and March $(n=9-11)$, species with asterisk between January and early April $(n=8$, except for $C$. aquatilis $n=1$ ). The bars represent mean values of all plants harvested in the respective periods ( $\pm 1 \mathrm{SE})$.

$74 \times 23 \mathrm{~mm}(300 \times 300 \mathrm{DPI})$ 


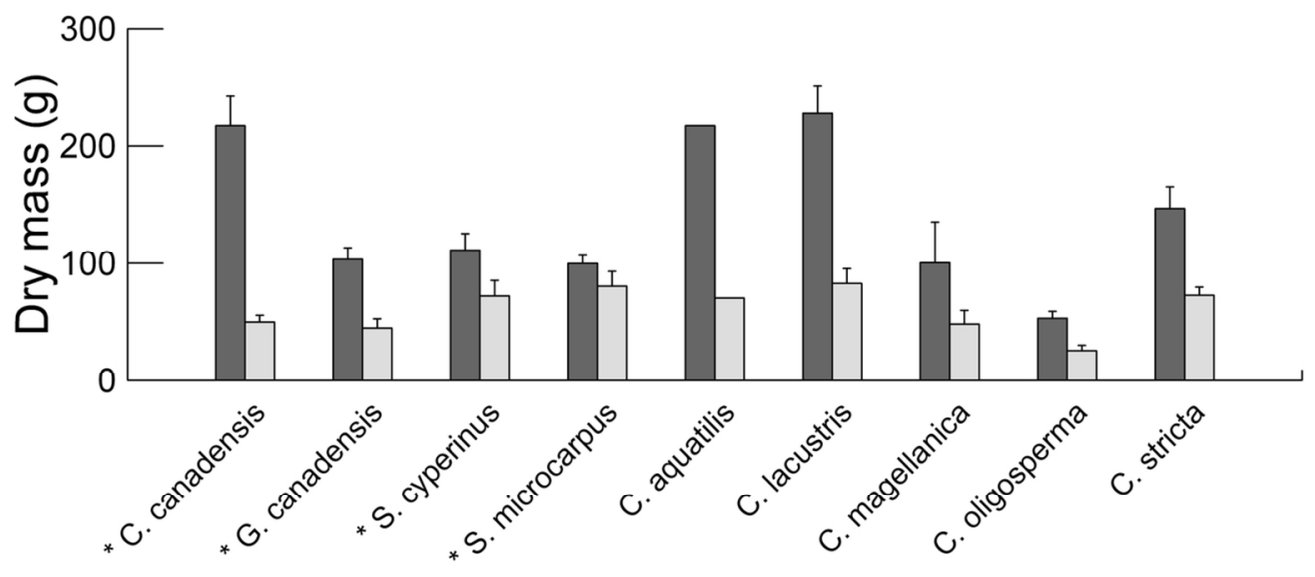

Fig. 2. Root dry mass during the winter for eight wetland monocot species at low (light grey) and high (dark grey) nutrient supply levels, and harvested after two growing seasons of growth in November-March (no asterisk; $n=9-11$ ) or in January-April (asterisk; $n=8$, expect for $C$. aquatilis $n=1$ ). The bars represent mean values of all plants harvested in the respective periods ( $\pm 1 \mathrm{SE})$.

$110 \times 51 \mathrm{~mm}(300 \times 300 \mathrm{DPI})$ 


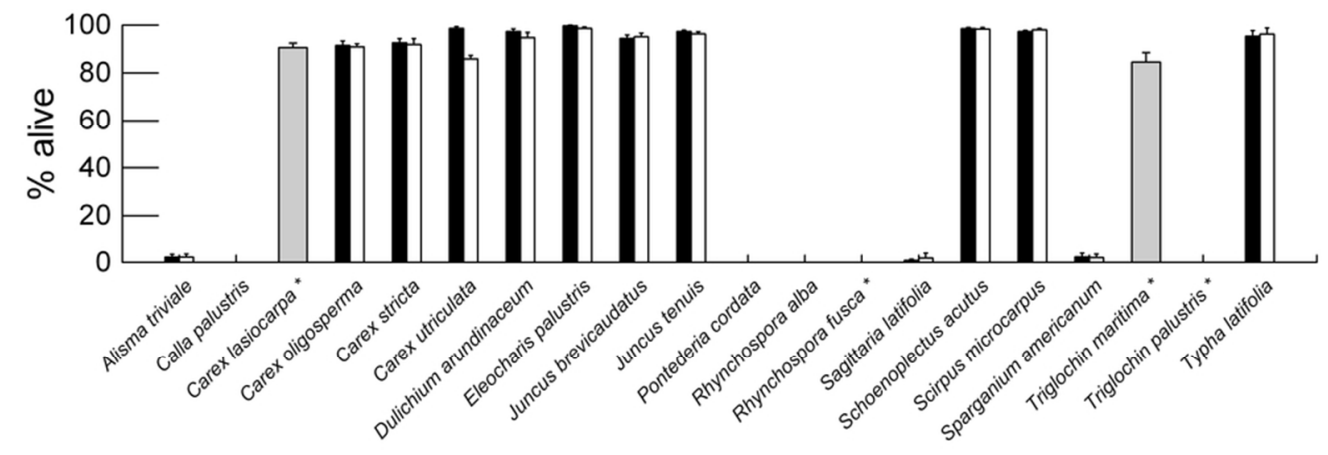

Fig 3. Percentage of living root length (TTC staining) in early May of 16 wetland monocot species. In 2013, the roots were collected either proximally $(1 \mathrm{~cm}$ below the stem; filled bars) or distally $(12 \mathrm{~cm}$ below the stem; open bars). For the species with an asterisk only one mixed sample (grey bars) per plant was collected in 2015 or 2017. $n=5$, except for the Triglochin species with $n=3$. Mean values $\pm 1 S E$.

$$
83 \times 29 \mathrm{~mm}(300 \times 300 \mathrm{DPI})
$$

